\title{
NICKEL RECOVERY FROM ELECTRIC ARC FURNACE SLAG BY MAGNETIC SEPARATION
}

\author{
Marianna Sakaroglou and Georgios N. Anastassakis \\ National Technical University of Athens (NTUA), School Mining Engineering and Metallurgy, \\ 15780 NTUA Campus, Zographou, Greece
}

(Received: July 22, 2017; Accepted: September 4, 2017)

\begin{abstract}
During the pyrometallurgical treatment of the nickel-bearing laterite in the plant of G.M.M. S.A. LARCO, slag is produced after treatment in electric-arc furnace (EAF) that contains 0.10 to $0.20 \%$ Ni. Taking into account the great quantity of slag produced per year, the recovery of nickel from the EAF slag will add benefits to the entire process. The target of the current work is to investigate the possibility of nickel recovery from EAF slag by magnetic separation. To meet the target, the effect of the following parameters was studied: grain size, magnetic field intensity, thickness of slag layer, moisture content, and re-grinding of the coarser slag particles. The results show that it is possible to obtain a magnetic product with nickel grade close to that of the primary raw material or even better, with sufficient nickel recovery.
\end{abstract}

Key words: magnetic separation; metal recovery; nickel-bearing laterite; nickel metallurgy; nickel slag.

\section{Introduction}

Nickel is the fifth most common element on earth. It is a lustrous, silvery-white metal with a high melting point of $1453{ }^{\circ} \mathrm{C}$. From metallurgical point of view, nickel is a versatile metal that easily forms alloys for various applications [1]. Nickel and its alloys are very important commercial items and possess an outstanding position in industrial and technological applications, outpacing almost all other industrial metals. This is due to the following specific properties of nickel: it is hard, ductile, malleable, can take a high polish, has low electrical and thermal conductivity, can be magnetized, and can act as chemical catalyst. Nickel-containing materials play a major role in human everyday life because, compared with other materials, they offer better corrosion and oxidation resistance, better toughness, better strength at high and low temperatures, high melting point, ductility, malleability, and a range of special magnetic and electronic properties $[2,3]$.

The major use of nickel is in the production of stainless and heat resisting steels, which accounts for $66 \%$ of the total nickel consumption. However, $12 \%$ of nickel is also used in the production of non-ferrous alloys, $5 \%$ for steel alloys, $7 \%$ for plating, $3 \%$ for casting, $2 \%$ for batteries, and $5 \%$ for other uses (catalysts, chemicals, coins, electronics, magnetics, etc.) [4]. The distribution of nickel uses is shown in Figure 1 , from which it derives that stainless steels and alloys represent more than $80 \%$ of the world nickel market. The most important alloys are those of iron, nickel and chromium, out of which stainless steels (frequently 8$12 \%$ nickel) possess the largest volume. Nickel based alloys -like stainless steel but

${ }^{\#}$ Corresponding author: ganastas@metal.ntua.gr 
with higher nickel contents- are used for more demanding applications (e.g., gas turbines and some chemical plants).

The nickel-containing materials are used in the following fields and industries (selected) to produce capital and consumer goods, as well as intermediate products: metal industry, offshore oil and gas industry, waste incineration, building and construction, electrical and electronic engineering, mechanical engineering, chemical industry, transportation industry (e.g., jet manufacturing, gas turbine engines), power generation, food preparation equipment, mobile phones, medical equipment, military applications, coin factory, etc.

To realize the significance of nickelcontaining products, it is enough to mention that about 300,000 end-use applications of nickel are known, with more than $75 \%$ of them being based on heat- and corrosionresistance properties of the materials [2]. The huge range of products may vary from the simplest ones -e.g., bathroom taps, doorknobs, cutlery, and curtain cladding- to the most technologically advanced -e.g., jet engines, heat exchangers, pipelines and valves for high-technology applications (offshore oil, gas industry, power stations, nuclear waste storage, etc.), PCBs, rechargeable batteries, etc.

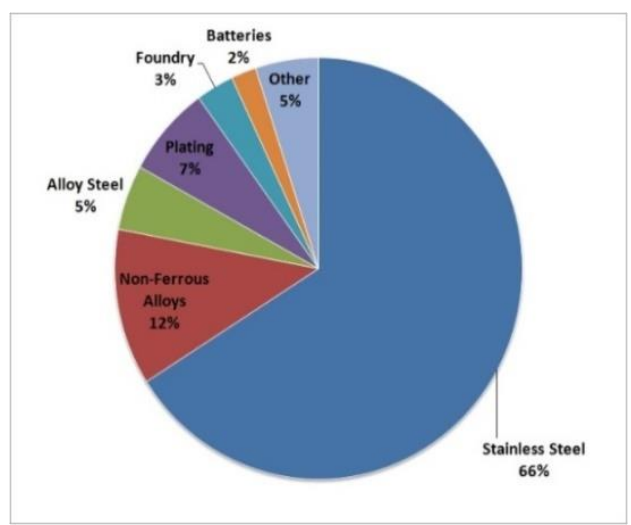

Figure 1. Uses of nickel
Nickel is mainly encountered in sulfide, and lateritic ores, with the latter being distinguished into limonite (or oxide type) and silicate type (saprolite). Although $75 \%$ of the global nickel-resources are laterites, their share in nickel production is currently less than $50 \%$. This preference for sulfide ores is mainly due to the difficulty in upgrading and processing laterite ores compared to sulfide ones, and the concomitant higher capital and operating cost. However, there is an increasing proportion of nickel production from laterite ores to meet the future demand. This leads to an important issue in terms of the environmental costs of nickel - as nickel production from laterite increases, the footprint per tonne of nickel metal could be expected to increase [5].

\section{Processing of nickel ores in Greece}

Greece is the only EU country with extensive but low grade nickeliferous laterite deposits, which are mainly confined in the central part of Evia Island, Neo Kokkino area and Viotia County (Central Greece), and Kastoria area (Western Macedonia).

The aforementioned laterite deposits are of sedimentary origin. The deposit in Kastoria area has been formed in "situ" by chemical weathering of ultramafic rocks (ophiolites), under certain environmental conditions; the deposits on Evia Island and in Central Greece have been formed after erosion of the ultramafic rocks, transportation of the eroded material away from the initial location by gravity or water, and re-deposition in new locations.

The whole mining operation and metallurgical processing of nickel laterite ores is run by GMM SA LARCO. In 2011, the overall ore mined was $2.2 \mathrm{Mt}$ with ferronickel production reaching to $18,500 \mathrm{t}$. The entire nickel quantity, which amounts to about $2 \%$ of the world production, was exported in the 
form of ferronickel alloy to European industries producing stainless steel. The metallurgical plant is located in Larymna (Fthiotida County), as shown in Figure 2 [4]. In general, laterite ore deposits may be treated by means of pyrometallurgical or hydrometallurgical processing [6, 7]. Most pyrometallurgical routes (ferronickel and matte smelting) use a conventional flow-sheet that usually includes upgrading in the mine, drying, further upgrading, calcining/reduction and electric furnace smelting followed either by refining to produce a ferronickel product or conversion to a low iron-containing matte. The two principal hydrometallurgical processes currently practiced are Caron and HPAL (High Pressure Acid Leaching) processes.

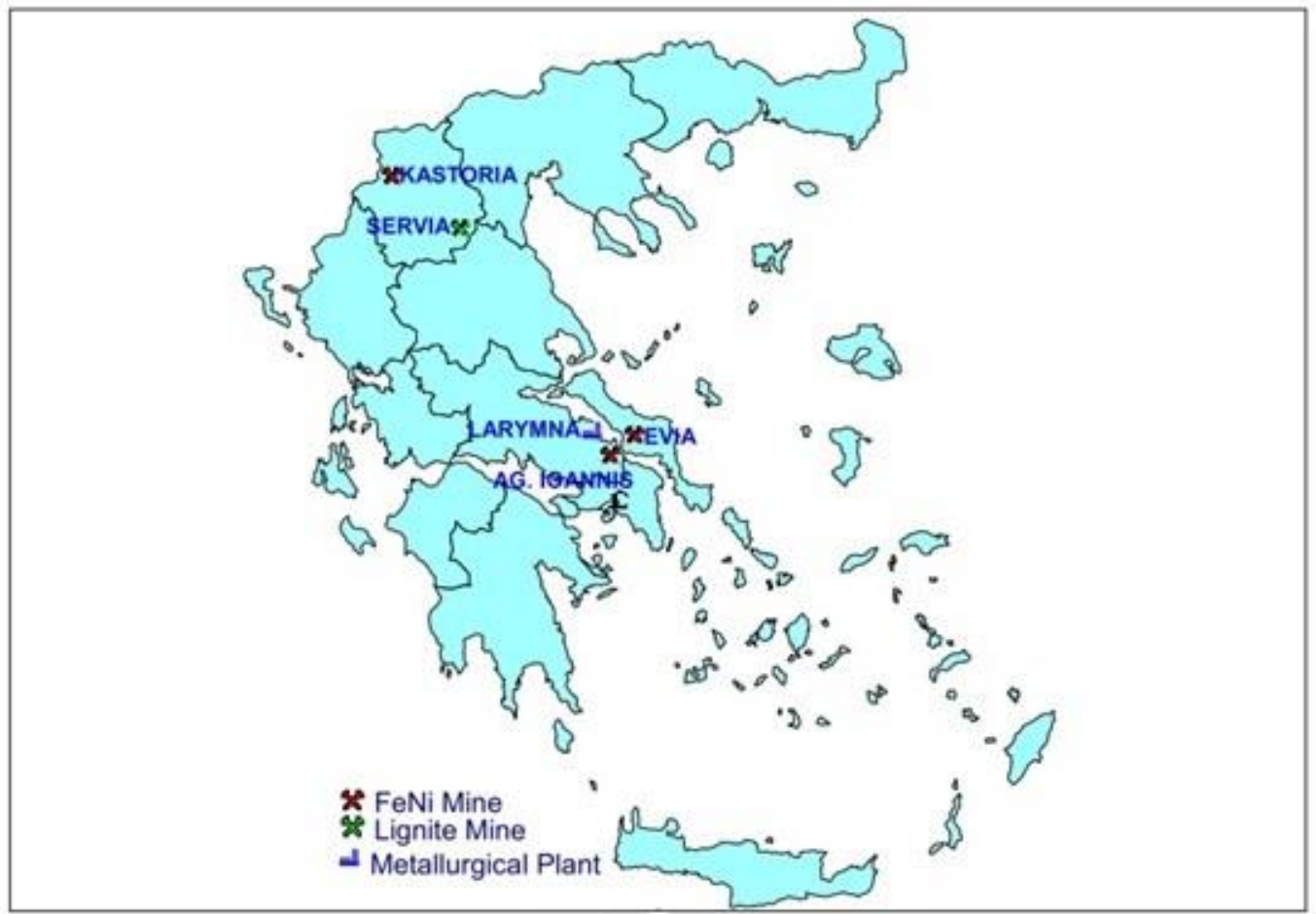

Figure 2. Areas of activity of G.M.M. S.A. LARCO

In the current case, nickel-bearing ores are treated pyrometallurgically in the plant of LARCO to produce ferronickel granules with 18-24\% nickel content [4].

The basic production line, which is shown in Figure 3 [8] consists of the following steps: mixing of primary raw materials (laterite, coal, lignite); pre-heating and pre-reduction in four rotary kilns; electric furnace reductive smelting in five sub-merged arc electrical furnaces; enrichment/refining into two OBMtype converters, of $50 \mathrm{t}$ capacity each, and granulation. The final product is high-purity, low-carbon ferronickel granules, which are used exclusively in stainless steel production.

Due to the mechanical losses of ferronickel in the electric furnace slag, the nickel content ranges between 0.10 and $0.20 \%$ while the amount of slag is about $2 \mathrm{Mt} / \mathrm{y}$. For this reason, the slag is crushed and submitted to low-intensity magnetic separation to recover the ferronickel into the magnetic product but this is not generally feasible. As a result, the recovery of magnetic separation is generally very low. 


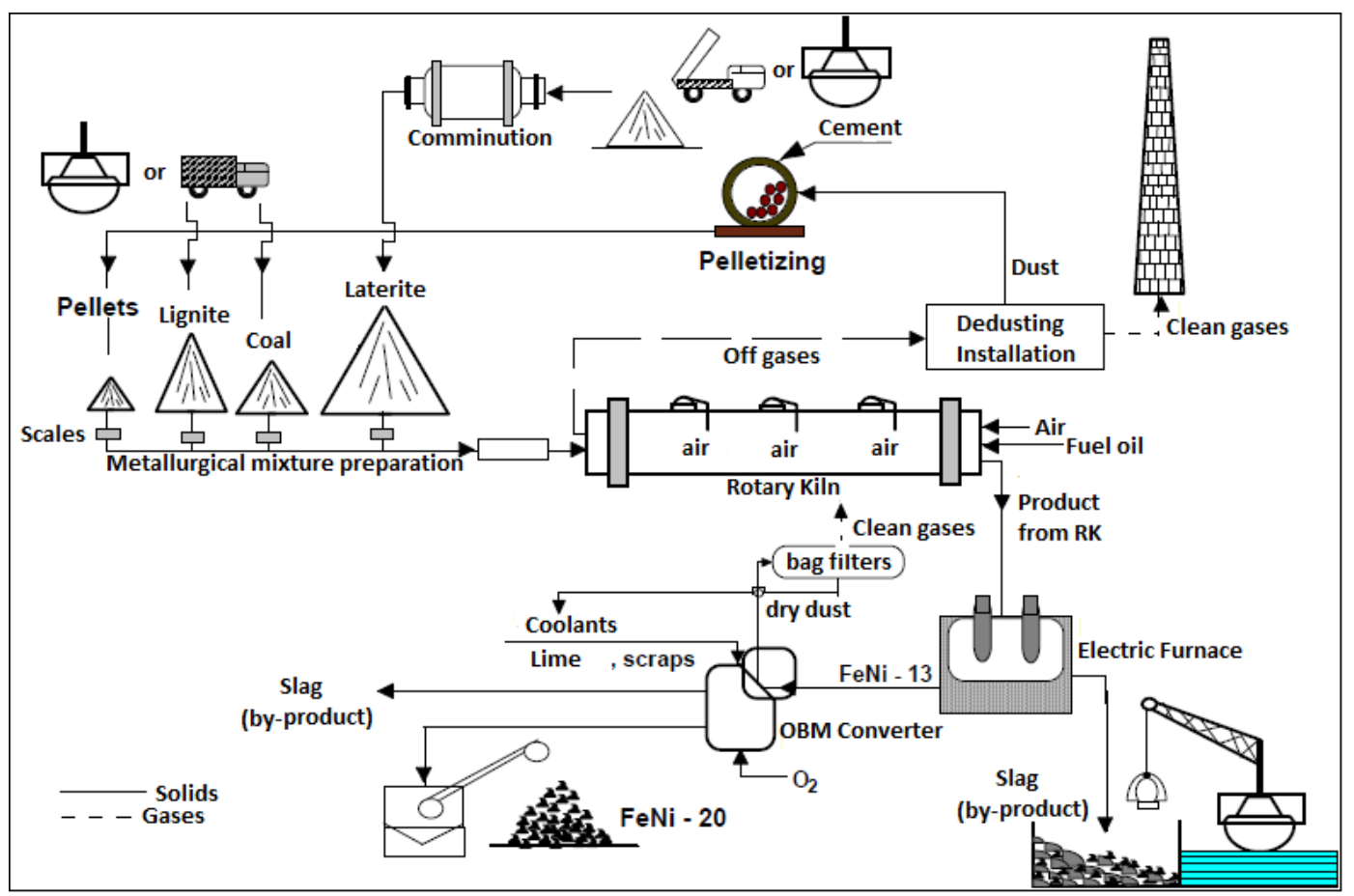

Figure 3. Flow-sheet applied in the metallurgical plant of LARCO

Slags from pyrometallurgical treatment of ores sometimes contain valuable metal in increased concentration because of the inefficient separation of metal phase from slag. Hence, they are actually considered as a secondary resource of metals rather than an end-waste and have been applied as a resource material in many areas [9-16]. According to the origin and characteristics, the principal slags can be classified into ferrous and nonferrous.

The most common metallurgical slags are those originated from iron, steel, alloy steel, ferroalloy and copper production. Because of their low iron content (less than 2\%), no attempt is made to recover iron from iron slags that originate from Blast Furnace (BF); on the contrary, iron slags are mostly used in other applications, such as cement production, road construction, civil engineering works, fertilizer production, landfill daily cover, soil reclamation, etc. [9].
In respect to the other common slags, the following methods have been applied for metal recovery:

- Steel slags. They are produced in Basic Oxygen Furnace (BOF) and Electric Arc Furnace (EAF). Because iron in the steel slags is normally encountered in the form of steel $(7-10 \%)$, iron oxide and iron bearing minerals, the recovery of iron is achieved by crushing or grinding, screening and magnetic separation [17]. Similarly to iron slags, steel slags can also be used in other applications.

- Alloy steel slags. The amount of alloy steel slags is small but they usually contain high amount of alloying elements (e.g., $\mathrm{Cr}$, $\mathrm{Ni}, \mathrm{Mn}, \mathrm{V}, \mathrm{Ti}, \mathrm{Mo}$ ), with stainless steel slag being the largest among the alloy steel slags. Because the latter slag contains high amount of $\mathrm{Cr}$ and a certain amount of $\mathrm{Ni}$, metal recovery is necessary prior to its application or landfilling by magnetic or gravity separation methods [10-12, 17, 18]. 
- Ferroalloy slag. This term includes FeMn, SiMn, charge chrome (CrFe with 50$55 \% \mathrm{Cr}$ ) slag, etc. Especially with charge chrome slag, the content in $\mathrm{Cr}$ and other metals is high; it is estimated that an almost equal amount of slag and metals is produced in a charge chrome plant. To recover $\mathrm{Cr}$ from charge chrome slag, magnetic and gravity separation methods have been used at bench and industrial scale $[19,20]$.

- Copper slag. The methods used to recover copper from slags are basically flotation, leaching and roasting [14]. This is because the mineralogical composition and phase grains within copper slags are quite different, depending on many factors such as the type of ores processed, the type of furnaces and the cooling methods [21]

In contrast to the aforementioned treatment of slags, dumping is the most usual method for slag settling. In such a case, plenty of land is occupied by slag, resources are wasted and severe environmental problems may arise to water and soil, due to the dissolution of deleterious metals and their migration from the slag to the soil and water.
The aim of the current work is to investigate the possibility of ferronickel recovery from the electric furnace slag by magnetic separation. To meet the target, the following factors were investigated during magnetic separation tests: grain size, magnetic field intensity, distance between material and magnet, thickness of slag layer, re-grinding of coarse grains, and moisture content.

\section{Experimental}

\subsection{Material Characterization}

The material used in the current research was slag from electric-arc furnace (EAF). The initial weight of the sample was $40 \mathrm{~kg}$. After successive sampling, two representative samples of about $3 \mathrm{~kg}$ each were obtained and used for mineralogical characterization, chemical and sieve analysis of the material, as well as for magnetic separation tests.

$\mathrm{X}$-ray diffraction and SEM analysis were employed for the mineralogical study of the slag (Figures 4, 5).

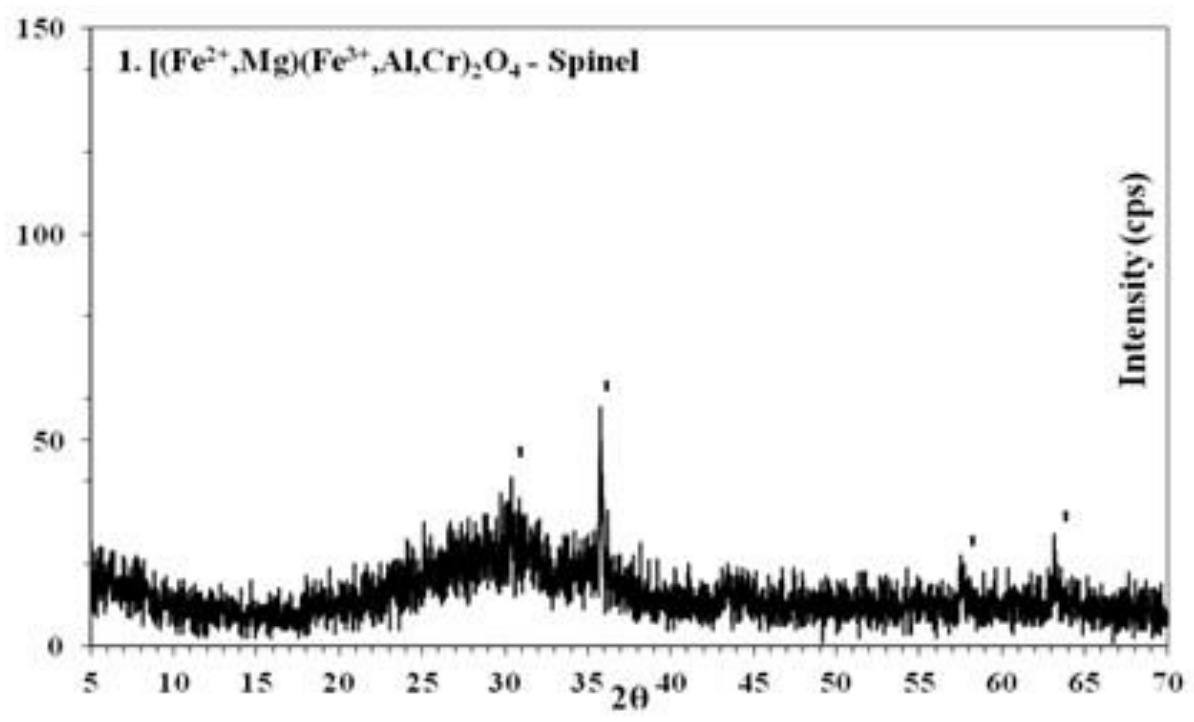

Figure 4. XRD analysis of EAF slag 


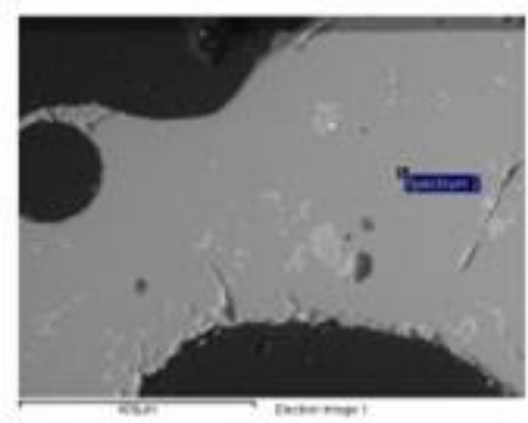

Amorphous

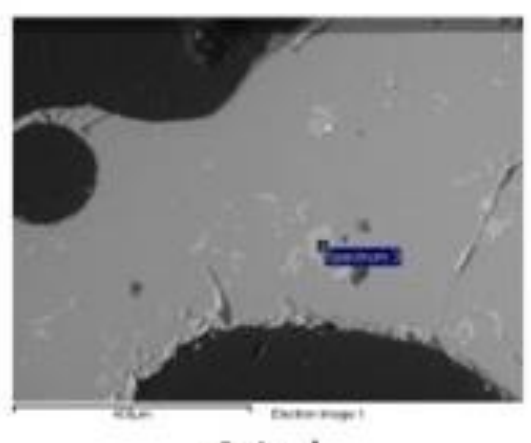

Spinel

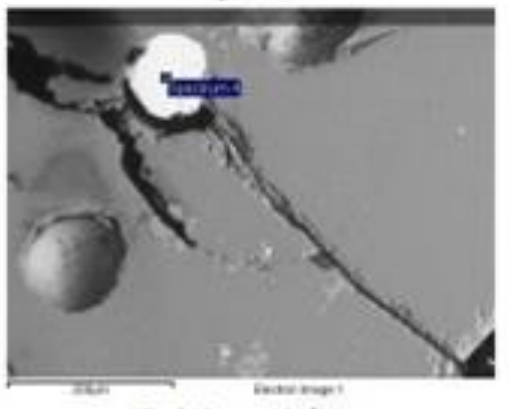

FeNi particles

Figure 5. SEM analysis of EAF slag

The results clearly show that a) the detected basic phases are amorphous slag, spinel, and FeNi particles, b) nickel is detected in no other phase unless as $\mathrm{FeNi}$, and c) $\mathrm{Cr}$ is detected only as spinel.

The results of chemical analysis (Table 1) show that the nickel content of the slag was $0.12 \% \mathrm{Ni}$, which is relatively low. In addition to nickel, the slag also contains $3.10 \% \mathrm{Cr}$ and $0.02 \% \mathrm{Co}$, while the moisture content is $4.25 \%$.
Table 1. Chemical analysis of EAF slag

\begin{tabular}{|c|c|}
\hline $\begin{array}{c}\text { Chemical } \\
\text { Element/Compound }\end{array}$ & Concentration (\%) \\
\hline $\mathrm{C}$ & 0.20 \\
\hline $\mathrm{S}$ & 0.16 \\
\hline $\mathrm{FeO}$ & 32.50 \\
\hline $\mathrm{Fe}_{2} \mathrm{O}_{3}$ & 4.03 \\
\hline $\mathrm{Fe}_{\text {total }}$ & 28.08 \\
\hline $\mathrm{Ni}$ & 0.12 \\
\hline $\mathrm{Co}$ & 0.02 \\
\hline $\mathrm{SiO}_{2}$ & 38.85 \\
\hline $\mathrm{CaO}$ & 4.95 \\
\hline $\mathrm{MgO}$ & 8.49 \\
\hline $\mathrm{Al} \mathrm{O}_{3}$ & 6.92 \\
\hline $\mathrm{Cr} \mathrm{O}_{3}$ & 3.10 \\
\hline $\mathrm{MnO}$ & 0.34 \\
\hline $\mathrm{CuO}$ & 0.03 \\
\hline $\mathrm{ZnO}$ & 0.07 \\
\hline $\mathrm{Moisture}$ & 4.25 \\
\hline
\end{tabular}

\subsection{Magnetic separation tests}

Three series of magnetic separation tests were carried out. The first series is referred to magnetic separation tests carried out on each sieve fraction with varying magnetic field intensity; in the second one, tests were carried out using variable thickness of slag layer and varying distance of magnet from the top of the feed; in the third series, there was examined the effect of re-grinding and moisture content.

During magnetic separation, both handmagnet and dry high-intensity magnetic separation (HIMS) were used. In the case of hand-magnet (low-intensity magnetic separator, LIMS), the intensity of the magnetic field was regulated by changing the distance of the magnet from the top of the material; in the case of HIMS, Type 138 $\mathrm{T}-\mathrm{C} 3 \mathrm{M}$, the tests were carried out with electric current intensity 0.5 and $1 \mathrm{~A}$, correspondingly.

To investigate the effect of slag-layer thickness, magnetic separation was carried out with layer thickness $4 \mathrm{~mm}$ and $2.8 \mathrm{~mm}$, 
correspondingly. In the case of re-grinding, the $+1.40 \mathrm{~mm}$ particle size, which was of higher nickel grade, was reduced to $-1.40 \mathrm{~mm}$ using roll crusher. Upon studying the effect of moisture, the water content was regulated by spraying defined water volume onto the slag sample.

\subsection{Results and Discussion}

\subsubsection{Effect of grain size}

The initial feed was submitted to sieving, and the various sieve fractions were chemically analyzed.

The results of chemical analysis clearly show that the nickel content of the coarser fractions is generally higher than that of the finer (Table 2).
In more details, the nickel grade of the sieve fraction $-8.00+2.80 \mathrm{~mm}$ is $0.84 \%$, which is inferior but close to that of the raw material (feed: $0.95 \% \mathrm{Ni}$ ); the yield of this particle size is approximately $11 \%$ of the initial, with corresponding nickel distribution almost 50 $\%$. On the contrary, the cumulative nickel grade of the $-1.40 \mathrm{~mm}$ fraction is $0.07 \%$, which is relatively low compared to that of the initial slag; the yield of this fraction is 71.65 $\%$ of the initial slag, with nickel distribution being $28 \%$.

The fraction $-2.80+1.40 \mathrm{~mm}$ has nickel grade $0.22 \%$, which is close to that of the feed, and nickel distribution about $17.5 \%$ due to the relatively increased yield (approx. $15 \%$ of the initial slag). Finally, the $+8.00 \mathrm{~mm}$ fraction, with a yield $2.40 \%$ only, has $0.39 \%$ Ni grade and $5 \%$ nickel distribution only.

Table 2. Results of particle size analysis of the slag

\begin{tabular}{|c|c|c|c|}
\hline $\begin{array}{c}\text { Particle Size } \\
\mathbf{m m}\end{array}$ & $\begin{array}{c}\text { Yield } \\
\mathbf{\%}\end{array}$ & $\begin{array}{c}\text { Nickel Grade } \\
\mathbf{\%}\end{array}$ & $\begin{array}{c}\text { Nickel Distribution } \\
\mathbf{\%}\end{array}$ \\
\hline+8.00 & 2.40 & 0.39 & 4.94 \\
\hline$-8.00+4.70$ & 5.08 & 0.84 & 22.64 \\
\hline$-4.70+2.80$ & 6.03 & 0.84 & 26.98 \\
\hline$-2.80+1.40$ & 14.84 & 0.22 & 17.43 \\
\hline$-1.40+1.18$ & 15.07 & 0.10 & 8.32 \\
\hline$-1.18+0.60$ & 17.82 & 0.07 & 7.07 \\
\hline$-0.60+0.30$ & 16.89 & 0.06 & 5.69 \\
\hline$-0.30+0.15$ & 16.86 & 0.06 & 5.43 \\
\hline-0.15 & 5.01 & 0.06 & 1.51 \\
\hline Feed & 100.00 & 0.19 & 100.00 \\
\hline
\end{tabular}

\subsubsection{Effect of magnetic field intensity}

Magnetic separation tests were carried out using either hand-magnet (low-intensity magnetic field) or dry HIMS. The first one was used for the $+1.18 \mathrm{~mm}$ fractions while the second for the finer than $1.18 \mathrm{~mm}$.

The results of magnetic separation along with the conditions are presented in Table 3. From this Table it clearly derives that the low intensity magnetic separation (LIMS), such as the magnetic field of a hand magnet, systematically provides a magnetic product with nickel grade higher than $1.10 \%$ for particle size $+2.80 \mathrm{~mm}$. This grade is higher than that of the raw laterite feed by 16 to 38 $\%$; the nickel recovery in the magnetic product is also high, ranging between 83 and $97 \%$.

Table 3 also shows that the results carried out with a HIMS are inferior to those carried out with a LIMS because of the low nickel 
grade of the magnetic product, despite the better liberation that occurs in the finer slag particles. Practically, there is no separation with the use of a high-intensity magnetic field for all the sieve fractions finer than $2.80 \mathrm{~mm}$. The reversal of nickel grade in the products of the $-0.60+0.30 \mathrm{~mm}$ fraction could be attributed to the entrapment of the magnetic particles in the non-magnetic product.

Considering the effect of current intensity on the magnetic product for the various fractions, the grade is reduced, as the intensity increases from 0.5 to $1.0 \mathrm{~A}$. In general, magnetic separation seems more efficient for slag particles coarser than $2.80 \mathrm{~mm}$.

Table 3. Results of magnetic separation

\begin{tabular}{|c|c|c|c|c|c|}
\hline $\begin{array}{c}\text { Particle Size } \\
\text { mm }\end{array}$ & $\begin{array}{c}\text { Current Intensity } \\
\text { A }\end{array}$ & Product & $\begin{array}{c}\text { Yield } \\
\%\end{array}$ & $\begin{array}{c}\text { Grade } \\
\% \mathrm{Ni}\end{array}$ & $\begin{array}{c}\text { Ni Distribution } \\
\%\end{array}$ \\
\hline+8.00 & Hand Magnet & $\begin{array}{c}\text { Magnetic } \\
\text { Non-Magnetic } \\
\text { Feed }\end{array}$ & $\begin{array}{c}35.39 \\
64.61 \\
100.00\end{array}$ & $\begin{array}{l}1.15 \\
0.13 \\
0.49\end{array}$ & $\begin{array}{c}83.1 \\
16.9 \\
100.0\end{array}$ \\
\hline$-8.00+4.70$ & Hand Magnet & $\begin{array}{c}\text { Magnetic } \\
\text { Non-Magnetic } \\
\text { Feed }\end{array}$ & $\begin{array}{c}65.92 \\
34.08 \\
100.00 \\
\end{array}$ & $\begin{array}{l}1.31 \\
0.07 \\
0.89\end{array}$ & $\begin{array}{c}97.3 \\
2.7 \\
100.0 \\
\end{array}$ \\
\hline$-4.70+2.80$ & Hand Magnet & $\begin{array}{c}\text { Magnetic } \\
\text { Non-Magnetic } \\
\text { Feed }\end{array}$ & $\begin{array}{c}47.98 \\
52.02 \\
100.00\end{array}$ & $\begin{array}{l}1.12 \\
0.10 \\
0.60\end{array}$ & $\begin{array}{c}89.6 \\
10.4 \\
100.0\end{array}$ \\
\hline$-2.80+1.40$ & Hand Magnet & $\begin{array}{c}\text { Magnetic } \\
\text { Non-Magnetic } \\
\text { Feed }\end{array}$ & $\begin{array}{c}12.18 \\
87.82 \\
100.00\end{array}$ & $\begin{array}{l}0.64 \\
0.08 \\
0.15\end{array}$ & $\begin{array}{c}52.6 \\
48.4 \\
100.0\end{array}$ \\
\hline$-2.80+1.40$ & 0.5 & $\begin{array}{c}\text { Magnetic } \\
\text { Non-Magnetic } \\
\text { Feed }\end{array}$ & $\begin{array}{c}15.36 \\
84.64 \\
100.00 \\
\end{array}$ & $\begin{array}{l}0.56 \\
0.06 \\
0.14 \\
\end{array}$ & $\begin{array}{c}61.4 \\
38.6 \\
100.0 \\
\end{array}$ \\
\hline$-2.80+1.40$ & 1.0 & $\begin{array}{c}\text { Magnetic } \\
\text { Non-Magnetic } \\
\text { Feed }\end{array}$ & $\begin{array}{c}90.08 \\
9.92 \\
100.00\end{array}$ & $\begin{array}{l}0.15 \\
0.05 \\
0.14\end{array}$ & $\begin{array}{c}96.5 \\
3.5 \\
100.0\end{array}$ \\
\hline$-1.40+1.18$ & Hand Magnet & $\begin{array}{c}\text { Magnetic } \\
\text { Non-Magnetic } \\
\text { Feed }\end{array}$ & $\begin{array}{c}5.42 \\
94.58 \\
100.00\end{array}$ & $\begin{array}{l}0.45 \\
0.07 \\
0.09\end{array}$ & $\begin{array}{c}27.1 \\
72.9 \\
100.0\end{array}$ \\
\hline$-1.40+1.18$ & 0.5 & $\begin{array}{c}\text { Magnetic } \\
\text { Non-Magnetic } \\
\text { Feed }\end{array}$ & $\begin{array}{c}14.30 \\
85.70 \\
100.00\end{array}$ & $\begin{array}{l}0.16 \\
0.08 \\
0.09\end{array}$ & $\begin{array}{c}25.4 \\
74.6 \\
100.0\end{array}$ \\
\hline$-1.40+1.18$ & 1.0 & $\begin{array}{c}\text { Magnetic } \\
\text { Non-Magnetic } \\
\text { Feed }\end{array}$ & $\begin{array}{c}95.41 \\
4.59 \\
100.00 \\
\end{array}$ & $\begin{array}{l}0.07 \\
0.06 \\
0.07 \\
\end{array}$ & $\begin{array}{c}95.4 \\
4.6 \\
100.0\end{array}$ \\
\hline$-1.18+0.60$ & 0.5 & $\begin{array}{c}\text { Magnetic } \\
\text { Non-Magnetic } \\
\text { Feed }\end{array}$ & $\begin{array}{c}18.15 \\
81.85 \\
100.00\end{array}$ & $\begin{array}{l}0.10 \\
0.08 \\
0.08\end{array}$ & $\begin{array}{c}22.7 \\
77.3 \\
100.0\end{array}$ \\
\hline$-1.18+0.60$ & 1.0 & $\begin{array}{c}\text { Magnetic } \\
\text { Non-Magnetic } \\
\text { Feed }\end{array}$ & $\begin{array}{c}97.11 \\
2.89 \\
100.00\end{array}$ & $\begin{array}{l}0.07 \\
0.06 \\
0.07\end{array}$ & $\begin{array}{c}97.1 \\
2.9 \\
100.0\end{array}$ \\
\hline$-0.60+0.30$ & 0.5 & $\begin{array}{c}\text { Magnetic } \\
\text { Non-Magnetic } \\
\text { Feed }\end{array}$ & $\begin{array}{c}57.34 \\
42.66 \\
100.00 \\
\end{array}$ & $\begin{array}{l}0.07 \\
0.09 \\
0.08 \\
\end{array}$ & $\begin{array}{c}50.2 \\
49.8 \\
100.0 \\
\end{array}$ \\
\hline
\end{tabular}




\subsubsection{Effect of magnet distance from the material}

The tests were carried out using a handmagnet, firmly fixed on specifically shaped edges of regulated height. The tests were carried out at distance almost nil, 1.0 and 2.0 $\mathrm{cm}$ from the top of the slag layer. The particle size of the slag was $+1.18 \mathrm{~mm}$.

The procedure was as follows: first, the magnetic separation was realized at almost nil distance; this test was realized by just passing the magnet in contact to the top of the layer; then, the magnetic product of the first stage underwent magnetic separation at a distance $1.0 \mathrm{~cm}$ from the top of the layer; finally, the magnetic product of the second stage underwent magnetic separation at a distance $2.0 \mathrm{~cm}$ from the top of the layer.

The results are shown in Table 4.

Table 4. Results of magnetic separation with varying distance of magnet from the slag layer

\begin{tabular}{|c|c|c|c|c|}
\hline $\begin{array}{c}\text { Distance } \\
\mathrm{cm}\end{array}$ & Product & $\begin{array}{c}\text { Yield } \\
\%\end{array}$ & $\begin{array}{c}\text { Ni Grade } \\
\%\end{array}$ & $\begin{array}{c}\text { Ni Recovery } \\
\%\end{array}$ \\
\hline Almost nil & Magnetic 1 & 13.17 & 0.89 & 52.9 \\
& Non-Magnetic 1 & 86.83 & 0.12 & 47.1 \\
& Feed & 100.00 & 0.22 & 100.0 \\
\hline 1.0 & Magnetic 2 & 11.87 & 0.97 & 52.2 \\
& Non-Magnetic 2 & 1.30 & 0.12 & 0.7 \\
& Magnetic 1 & 13.17 & 0.89 & 52.9 \\
\hline 2.0 & Magnetic 3 & 11.52 & 0.99 & 51.6 \\
& Non-Magnetic 3 & 0.35 & 0.35 & 0.6 \\
& Magnetic 2 & 11.87 & 0.97 & 52.2 \\
\hline
\end{tabular}

The results of Table 4 show that at the minimum distance of magnet from the top of the slag, a magnetic product is obtained with $0.89 \% \mathrm{Ni}$ grade, which is of the same order with that of the primary raw ore, and nickel recovery about $53 \%$. The gradual increase of separation distance increases the grade of the magnetic product to about $1 \% \mathrm{Ni}$, without significant reduction of nickel recovery.

\subsubsection{Effect of slag-layer thickness}

These tests were carried out through a hand-magnet using the $-2.80+1.40 \mathrm{~mm}$ particle fraction of the slag. The corresponding layer thickness was $2.8 \mathrm{~mm}$ (monolayer) and $4 \mathrm{~mm}$. The material was fed onto a conveyor belt and submitted to magnetic separation, passing below a hand- magnet, which was fixed above the belt. The magnet was placed just above the top of the slag layer.

The results of magnetic separation are shown in Figure 6.

These results show that for a layer thickness $2.8 \mathrm{~mm}$ (monolayer of slag particles) the yield and recovery are $7 \%$ and almost $53 \%$, correspondingly. These values are significantly higher than the corresponding for $4.0 \mathrm{~mm}$ thickness, which are $3 \%$ for the yield and $33 \%$ for the recovery. This is rather due to the entrapment of magnetic particles at the lower part of the $4.0 \mathrm{~mm}$ layer.

This is also sustained by the nickel grade of the non-magnetic products, which are $0.07 \%$ for $2.8 \mathrm{~mm}$ layer thickness and $0.09 \%$ $\mathrm{Ni}$ for $4.0 \mathrm{~mm}$ thickness. 


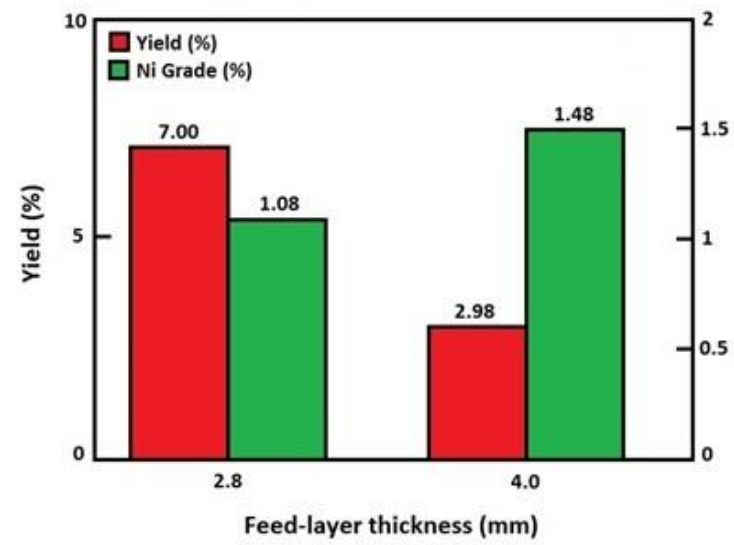

a)

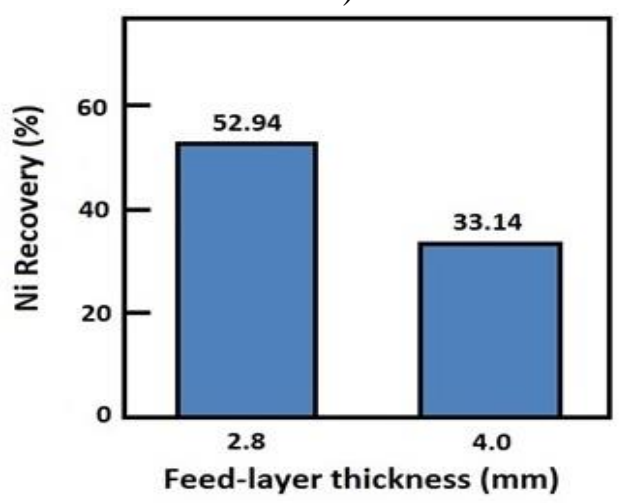

b)

Figure 6. Effect of the feed-layer thickness of the slag on the metallurgical results of the magnetic product
In reference to the grade of the magnetic products, the grade for the $4.0 \mathrm{~mm}$ layer is about $50 \%$ higher than that for $2.8 \mathrm{~mm}$ thickness (compare $1.48 \% \mathrm{Ni}$ for $4.0 \mathrm{~mm}$ thickness to $1.08 \% \mathrm{Ni}$ for $2.8 \mathrm{~mm}$ ). In any case, the grade of the magnetic product is higher than that of the primary raw laterite but the case of slag feeding in monolayer arrangement is considered more favorable because of the higher nickel recovery.

\subsubsection{Effect of slag re-grinding}

To study the effect of re-grinding on the quality of the magnetic product, the $+1.40 \mathrm{~mm}$ size fraction of the slag was re-ground to $1.40 \mathrm{~mm}$ in a roll crusher. The magnetic separation was carried out in the same way as that concerning the effect of slag-layer thickness. The results of magnetic separation after re-grinding are shown in Table 5.

The comparison of the results of magnetic separation by hand-magnet shows that the grade of the magnetic material after regrinding is practically the same with that of the initial (coarse) slag, despite the slightly inferior grade, while the grade of the nonmagnetic product slightly increases. The magnetic product after re-grinding has considerably lower yield and recovery.

Table 5. Magnetic separation of the coarser slag particles after re-grinding

\begin{tabular}{|c|c|c|c|c|}
\hline Slag & Product & Yield \% & Ni Grade \% & Recovery \% \\
\hline Initial & Magnetic & 31.40 & 1.10 & 87.8 \\
& Non-Magnetic & 68.60 & 0.07 & 12.2 \\
& Feed & 100.00 & 0.39 & 100.0 \\
\hline Re-ground & Magnetic & 24.07 & 1.07 & 76.9 \\
& Non-Magnetic & 75.93 & 0.10 & 23.1 \\
& Feed & 100.00 & 0.34 & 100.0 \\
\hline
\end{tabular}

Based on the aforementioned results, it derives that re-grinding of the $+1.40 \mathrm{~mm}$ slag particles to $-1.40 \mathrm{~mm}$ doesn't make any benefit, as it should be anticipated because of the higher liberation degree. This could be attributed to the generation of fines that adversely affect dry magnetic separation. In more details, fine magnetic particles may not be attracted by the magnet because of their small mass, and the concomitant weak magnetic force; also, fine magnetic particles may be covered by coarser non-magnetic 
particles that prevent their motion towards the magnet. This assumption is sustained by the higher grade and the higher nickel loss in the non-magnetic product after grinding, while the grade of the magnetic product practically remains unaffected.

\subsubsection{Effect of moisture content}

To study the effect of moisture content on magnetic separation, two tests were carried out. In the first, it was used the initial slag (moisture content $4 \% \mathrm{w} / \mathrm{w}$ ). The second test was carried out on slag with moisture content of $8 \% \mathrm{w} / \mathrm{w}$ by spraying the initial slag with calculated volume of water. The separation was carried out on particle size $+1.18 \mathrm{~mm}$.

The results of magnetic separation are shown in Table 6.

The results show that the increase of water content adversely affects magnetic separation, as the grade of the magnetic product drops from $0.98 \%$ to $0.72 \% \mathrm{Ni}$; the corresponding yield reduces from $25.82 \%$ to $24.76 \%$, and the recovery reduces significantly from $81 \%$ to $66.5 \%$.

Table 6. Effect of moisture content of the slag on magnetic separation

\begin{tabular}{|c|c|c|c|c|}
\hline $\begin{array}{c}\text { Moisture } \\
\mathbf{\%} \mathbf{w} / \mathbf{w}\end{array}$ & Product & $\begin{array}{c}\text { Yield } \\
\mathbf{\%}\end{array}$ & $\begin{array}{c}\text { Ni Grade } \\
\mathbf{\%}\end{array}$ & $\begin{array}{c}\text { Ni Recovery } \\
\mathbf{\%}\end{array}$ \\
\hline 4 & Magnetic & 25.82 & 0.98 & 81.0 \\
& Non-Magnetic & 74.18 & 0.08 & 19.0 \\
& Feed & 100.00 & 0.31 & 100.0 \\
\hline 8 & Magnetic & 24.76 & 0.72 & 66.5 \\
& Non-Magnetic & 75.24 & 0.12 & 33.5 \\
& Feed & 100.00 & 0.27 & 100.0 \\
\hline
\end{tabular}

Also, the increase of moisture content results in the increase of nickel grade in the non-magnetics from $0.08 \% \mathrm{Ni}$ ( $4 \%$ moisture) to $0.12 \% \mathrm{Ni}$ (8\% moisture). This could be possibly attributed to the stronger adhesion forces between particles as moisture content increases that prevent particles from effective separation (entrapment of magnetics in the non-magnetic product or vice versa).

\section{Conclusions}

During the pyrometallurgical treatment of various concentrates, metal losses in the slag are inevitable because of the inefficient separation of liquid metal phase from the liquid slag. This results in the reduced metal recovery and revenues from metal sales. In the case of nickel laterite treatment in Greece, the slag from electric-arc furnace (EAF) contains $0.10-0.20 \% \mathrm{Ni}$. This fact along with the great quantity of slag that is produced per year necessitates the recovery of nickel from the EAF slag to improve the overall economics of ferronickel production.

The size classification of the EAF slag reveals that the coarser particles have increased nickel grade, which is slightly inferior to that of the raw laterite feed, and satisfactory nickel recovery. Also, the slag underwent magnetic separation as potential method to recover nickel from the slag. The results show that low intensity magnetic separation could be efficiently applied, as the grade of the magnetic product ranged from 0.9 to $1.5 \% \mathrm{Ni}$, which is much higher than the grade of the raw laterite feed; the corresponding nickel recovery was satisfactory, as it was higher than $80 \%$.

In conclusion, the results of magnetic separation clearly show that nickel separation from EAF slag seems feasible under the prerequisite of well-controlled operational conditions. 


\section{Acknowledgements}

The authors are indebted to the staff of Chemistry Department of G.M.M. S.A. LARCO and Dr. Petros Tsakiridis, Chem. Eng., MSc - PhD, Laboratory of Physical Metallurgy - NTUA for their contribution in the current work by conducting the chemical analyses as well as XRD and SEM analyses correspondingly.

\section{References}

[1] British Geological Survey (2008) Nickel, $24 \mathrm{p}$.

[2] INSG (2014) World Directory of Nickel Production Facilities, 206p.

[3] Ashcroft, G. (2014) Nickel Laterites: The World's Largest Source of Nickel, http://www.geologyforinvestors.com/ (accessed: May 26, 2017).

[4] LARCO G.M.M. S.A. (2017) http://www.larco.gr/nickel.php (accessed: July 7, 2017)

[5] Mudd, G.M. (2009) Nickel Sulfide versus Laterite: The Hard Sustainability Challenge Remains, Proceedings " $48^{\text {th }}$ Annual Conference of Metallurgists", Canadian Metallurgical Society, Sudbury, Ontario, Canada, August 2009.

[6] Oxley, A., Smith, M.E., Caceres, O. (2016) Why heap leach nickel laterites?, Minerals Engineering 88, 53-60.

[7] Dalvi, A., Bacon, G., Osborne, R. (2004) The Past and the Future of Nickel Laterites, PDAC 2004 International Convention, Trade Show \& Investors.

[8] INSG (2014) World Directory of Nickel Production Facilities - Flowcharts, 44p.

[9] Shen, H., Forssberg, E. (2003) An overview of recovery of metals from slags, Waste Management 23, 933-949.

[10] Dildin, A.N., Chumanov, I.V. (2015) Study of the processes of metal recovery from steel slags, Indian Journal of Science and Technology 8 (34).

[11] Jones, R.T. (2004) Economic and environmentally beneficial treatment of slags in DC arc furnaces, Economic and environmentally beneficial treatment of slags in DC arc furnaces, VII International Conference on Molten Slags, Fluxes and Salts, The South African Institute of Mining and Metallurgy.

[12] Bölükbasi, O.S, Tufan, B. (2014) Steelmaking slag beneficiation by magnetic separator and impacts on sinter quality, Science of Sintering 46, 331-344.

[13] Yang, H., Jing, L., Zhangb, B. (2011) Recovery of iron from vanadium tailings with coal-based direct reduction followed by magnetic separation, Journal of Hazardous Materials 185, 1405-1411.

[14] Sanchez, M., Parada, F., Parra, R., Marquez, F., Jara, R., Carrasco, J.C., Palacios, J. (2004) Management of copper pyrometallurgical slags: giving additional value to copper mining industry, VII International Conference on Molten Slags Fluxes and Salts, The South African Institute of Mining and Metallurgy.

[15] Pan, J., Zheng, G-L., Zhu, D-Q., Zhou, X-L. (2013) Utilization of nickel slag using selective reduction followed by magnetic separation, Trans. Nonferrous Met. Soc. China 23, 3421-3427.

[16] Yang, D.C., van Reenan, R., Bhimsan, V. (2003) Separation of metals from a slag using a multi-cell jig, Journal of Minerals \& Materials Characterization \& Engineering 2 (2), 137-144.

[17] Radosavljevic, S., Milic, D., Gavrilovski, M. (1996) Mineral processing of a converter slag and its use in iron ore sintering, Magnetic and Electrical Separation 7 (4), 201-211. 
[18] Lopez, F.A., Lopez-Delgado, A., Balcazar, N. (1996) Physico-chemical and mineralogical properties of EAF and AOD slags, Afinidad 53 (461), 39-46.

[19] Das, B., Mohanty, J.K., Reddy, P.S.R., Ansari, M.I., (1997) Characterization and beneficiation studies of charge chrome slag, Scandinavian Journal of Metallurgy 26 (4), 153-157.
[20] Khan, S.A., Ray, G., Sinha, M.K., Rao, P.V.T. (2001) Recovery of charge chrome from mixed metal and granulated slag, Tata Search (India) 115-118.

[21] Gbor, P.K., Mokri, V., Jia, C.Q. (2000) Characterization of smelter slags. Journal of Environmental Science and Health, Part A: Toxic/Hazardous Substances and Environmental Engineering 35 (2), 147167. 